\title{
Pärimus maastikul, maastik pärimuses: Hargla kihelkonna näitel ${ }^{1}$
}

Marju Kõivupuu

\begin{abstract}
Teesid: Artiklis antakse sissevaade Hargla kihelkonna kohapärimuse dünaamikasse ning ülevaade kohapärimuse tähtsusest ja tähendusest ning neist mõjutavatest teguritest kihelkondlikus kultuuriruumis nüüdisajal, võttes aluseks 2012. aasta suvel Hargla kihelkonnas toimunud välitööd, mille lähteülesandeks oli looduslike pühapaikade ja arheoloogiamälestiste inventeerimine ning nende kohta suulise pärimuse kogumine.
\end{abstract}

Märksõnad: Hargla kihelkond, kabeliasemed, kohapärimus, looduslikud pühapaigad, matusekombestik, rahvausund

\section{Sissejuhatus}

Vaieldamatult on maastik üks huvitavamaid vahendeid, viise ja võimalusi meid ümbritseva kultuuri mõtestamiseks ning ühiskonna ja selle liikmete identiteedimäärangute peegeldamiseks. Lihtsustatult võime kõnelda tänapäeval kahest maastikudiskursusest: ökoloogilisest ${ }^{2}$ ja semiootilisest (Cosgrove 2003: 15). Väites, et maastikul on mälu, personifitseerib inimene maastikku ning maastik saab seeläbi inimeste suulise ja kirjutatud ajaloo lahutamatuks osaks. Maastiku inimlik aspekt avaldub ka definitsioonis, mille kohaselt tähendab maastik inimeste poolt tajutavat maa-ala, mille tunnusjooned on kujunenud välja looduslike ja/või inimlike tegurite toime ja koostoime tulemusel. Looduse ja/või inimtegevuse jäljed ning nende jälgede representatsioonid maastikus on omakorda möödunud sajanditesse või koguni aastatuhandetesse tagasi ulatuva sündmusteahela osa. Paljud lülid selles ahelas ei ole meile enam ei nähtavad ega ka mäletatavad, kuid toimunu põhjusi ja tagajärgi ühendav minevik peegeldab nii maastiku muudatusi kui ka muudatuste jätkuvust ning osutab otseselt või 
kaudselt neist muutustest ja muudatustest inspireeritud maastikurepresentatsioonidele (KrEm 2003: 1, 7, 14).

Ka maastikuga seotud pärimus ulatub ajas ja ruumis määratult kaugemale või sügavamale (loodus)teadusliku geograafia tuumast ning geograafide poolt süstematiseeritud geograafilistest teadmistest, kui parafraseerida Wrighti (1947). Maastikus võivad kajastuda ja kajastuvadki võimusuhted, perekondlikud, etnilised ja sugukondlikud sidemed; keel ja selle areng; religioossed, poliitilised, majanduslikud ja sotsiaalsed süsteemid; kunsti, arhitektuuri ja tööstuse traditsioonid; lähi- ja kaugem ümbrus ning ühised piirid naabritega. Lähimaastikud peegelduvad inimeste materiaalses ja vaimses kultuuris: ehitistes, rahvariietes, uskumustes ja kommetes, poeetilises folklooris, (rahva) muusikas, kirjanduses, maastikumaalides, ajaloos ja poliitikas - kasvõi näiteks riigihümnis (Claval 2004). Erinevad märgid ja/või pärimusmälestised maastikus toetavad sotsiaalsete või etniliste gruppide mälu, toodavad narratiive, pannes omakorda aluse nn dialoogilisele ajaloole (history-in-dialogue) (Weiner 1991: 50).

Maastiku kujunemine religioosseteks ning ajaloolist mälu kandvateks paikadeks sünnib suuresti inimkäitumise, sealhulgas nimetamise (ametlik ning pärimuspõhine mikro- ja makrotoponüümika), jutustamise (rahvaluule, sh muistendid jm kohapärimus) ja konkreetse märgistamise kaudu ning suuresti suulise traditsiooni abil või toel (Fox 1997: 8-9; Siikala 1998; Rønnow 2011: 225). Seega on maastiku rolli identiteediloome ja ajaloolise mälu kujundajana raske alahinnata. Maastikul asuvate pärimusmälestiste ja mälupaikade kaudu peegelduvad otseselt või kaudselt ka inimese ja looduse suhted ning avaneb mõiste 'püha' (Rønnow 2011).

Artiklis annan sissevaate Hargla kihelkonna kohapärimuse dünaamikasse ning mõningase ülevaate kohapärimuse tähtsusest ja tähendusest kihelkondlikus kultuuriruumis nüüdisajal, samuti neid mõjutavatest teguritest, võttes aluseks 2012. aasta suvel Hargla kihelkonnas toimunud välitööd, mille lähteülesandeks oli looduslike pühapaikade ja arheoloogiamälestiste inventeerimine ja passistamine ${ }^{3}$ ning nende kohta suulise pärimuse kogumine. Sisuliselt tähendas see, et maastikul tuli võimalikult täpselt üles leida, kaardistada ja kirjeldada kohad, mille kohta esmajoones Eesti Rahvaluule Arhiivis (kuid ka teistes kogudes) leidub kohapärimuslikku teavet kas siis uskumusteadete või pikemate kohalugude (muistendid, usundilised jutud vms) näol (vt lähemalt: uurimismetoodika). Teisena käsitlen põgusalt maastiku ja võimu diskursust kohapärimuse (taas)loojana, (re)konstrueerijana; samuti küsimust, kas, ja kui, siis kellel on tänapäeval õigus maastikku oma äranägemise järgi tähistada ning seeläbi (taas)värskendada, (taas)korrastada maastiku mälu või toimida maastikku märgistades rahvausundist tuntud mütoloogilise tegelase - eksitajana. 


\section{Uurimismetoodika}

Päritolukihelkonnas välitööde tegemisse on vältimatult sisse kirjutatud balansseerimine eemilise (emic) ja eetilise (etic) skaalal ning vaieldamatult on sellel skaalal piirid üsna hägused (kui üldse saab sellisel juhul mingites piiridest kõnelda). Minu uurija intrepretatsioon (etic-lähenemine) toetub (ala)teadlikult emic-vaatenurgale, mis omakorda põhineb nüüdseks ca 40-45 aastat kestnud rohkem või vähem teadlikel osalusvaatlustel (sh lapsepõlves kogetu, kuuldu ja nähtu), mis mitmete kaasaegsete teoreetikute hinnagul (Pink 2000; Ruotsala 2001; vt ka intervjuu Katharine Youngiga, Alekand \& Metsvahi 2013) on nii mõnelgi juhul sageli usalduväärsem, kui seda on traditsiooniline intervjuu või küsitlus, mille puhul küsitletav püüab sageli vastata küsitleja ootustele. Viimast väidet kinnitavad ka siinkirjutaja suhteliselt pikaaegsed välitööde kogemused ajaloolisel Võrumaal 1980. aastate lõpust 2000. aastate alguseni.

Välitööde eel töötasime läbi Hargla kihelkonna kohta varasemal perioodil kirja pandud arheoloogiliste teadete, looduslike pühapaikade ning kohapärimusega seotud andmestiku Eesti Rahva Muuseumi, Eesti Rahvaluule Arhiivi, Eesti Kultuuriloolise Arhiivi, Eesti Keele Instituudi, Ajaloo Instituudi, Eesti Ajaloomuuseumi, Võru Instituudi ja Mõniste muuseumi kogudes; samuti Hargla kihelkonna aja- ja kultuurilugu puutuvad trükised, perioodika ja elektroonilised andmebaasid.

Kohapärimuse kameraalanalüüsi teoreetilise eelduse ja rakendusliku lähtekohana arvestasime, et 20. sajandi teise pooleni keskendus kohalugude ja uskumusteadete kogumise spetsiifika esmajoones rahvajutule või uskumusteatele kui kunstilisele tekstile, pöörates vähem tähelepanu jutustaja isikule ja/ või pärimusteate seotusele konkreetse koha või paigaga (vt ka Hiiemäe 2007; Remmel 2007 jt). Informantide hankimiseks kasutasime välitöödel sotsioloogias tuntud nn lumepallimeetodit: isiklike kontaktide vahendatud võtmeisikud juhatasid meid järgmiste inimeste juurde, kes on (ka mitmeid põlvi) kohalikud, tunnevad ja oskavad hästi lugeda maastikku ning võivad leida muutunud maastikupildis umbkaudu üles ka need foklooritekstides kirjeldatud kohad, mis looduses on nüüd juba raskesti leitavad või vaevu aimatavad. Küsitledes kasutasime peamiselt avatud intervjuu ja vaba vestluse meetodit. Intervjueerimine toimus alati ka konkreetses paigas, kohas, mida küsitletu või teejuht oskas meile näidata või mille kohta teadis rääkida lugusid. Võtmeinformantidega sõitsime inventeeritavad kohad läbi vähemalt üks, vajadusel ka kaks korda. GPS-iga kaardistamine toimus välitööde lõppfaasis, kui inventeeritavate paikade asukohad olid maastikul juba eelnevalt võimalikult täpselt kindlaks tehtud. Arvestades uurimisteema delikaatsust ${ }^{4}$ ja eetilisi kriteeriume ning soovi saada usaldusväärseid andmeid, toimusid välitööd ilma avaliku reklaamita. 


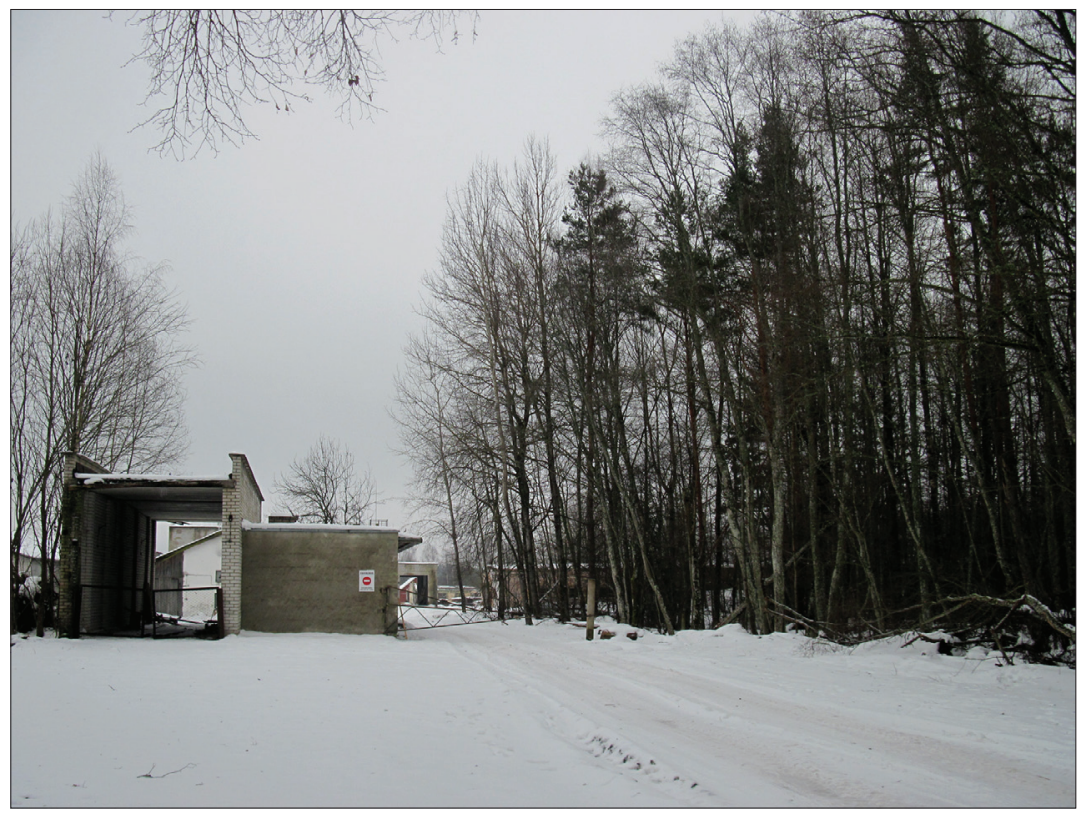

Foto 1. Kusagil siin peaks asuma kunagise Katri kabeli ase või hilisem Põhjasõjaaegne kalmistu. 1960. aastatel ehitati samasse kolhoosi lehmalaut, kuid sellestki pole enam nähtavaid jälgi. Marju Kõivupuu foto 2012.

Kaks töörühma liiget, Marju ja Kaarel Kõivupuu on Edward Relphi (Relph 1976) määratluse kohaselt “ühe jalaga seesolijad”, kelle esivanemad on elanud Hargla kihelkonnas Mõniste ja Taheva-Laanemetsa ümbruses teadaolevalt vähemalt 5-6 põlve. M. Kõivupuu on Hargla kihelkonnas teinud süsteemselt välitöid 1989., 1990. ja 1991. aastal, hiljem individuaalselt ja juhuslikult ning tegelenud 1990. aastatest ristipuude uurimise, inventeerimise ja kaitse korraldamise küsimustega.

\section{Hargla kihelkond: ajaloolist}

Hargla (võru keeles Harglõ) on Eesti üks väikseimaid ja lõunapoolsemaid kihelkondi. See on ajaloolise Võrumaa kõige läänepoolsem kihelkond, mis moodustati Karl XI korraldusel 1694. aastal Koivaliina (läti Gaujiena, saksa Atzele või Adzele), Urvaste ja Karula kihelkonna maadest, põhjuseks kakskeelne kogudus ja keerulised loodusolud. Koiva (läti Gauja, saksa Aa) ja Mustjõe kevadine ning sageli ka sügisene üleujutus muutis ühenduse pidamise Koivaliinaga peaaegu võimatuks. Paiknemine Eesti ja Läti piirialal on mõjutanud-kujundanud kihel- 


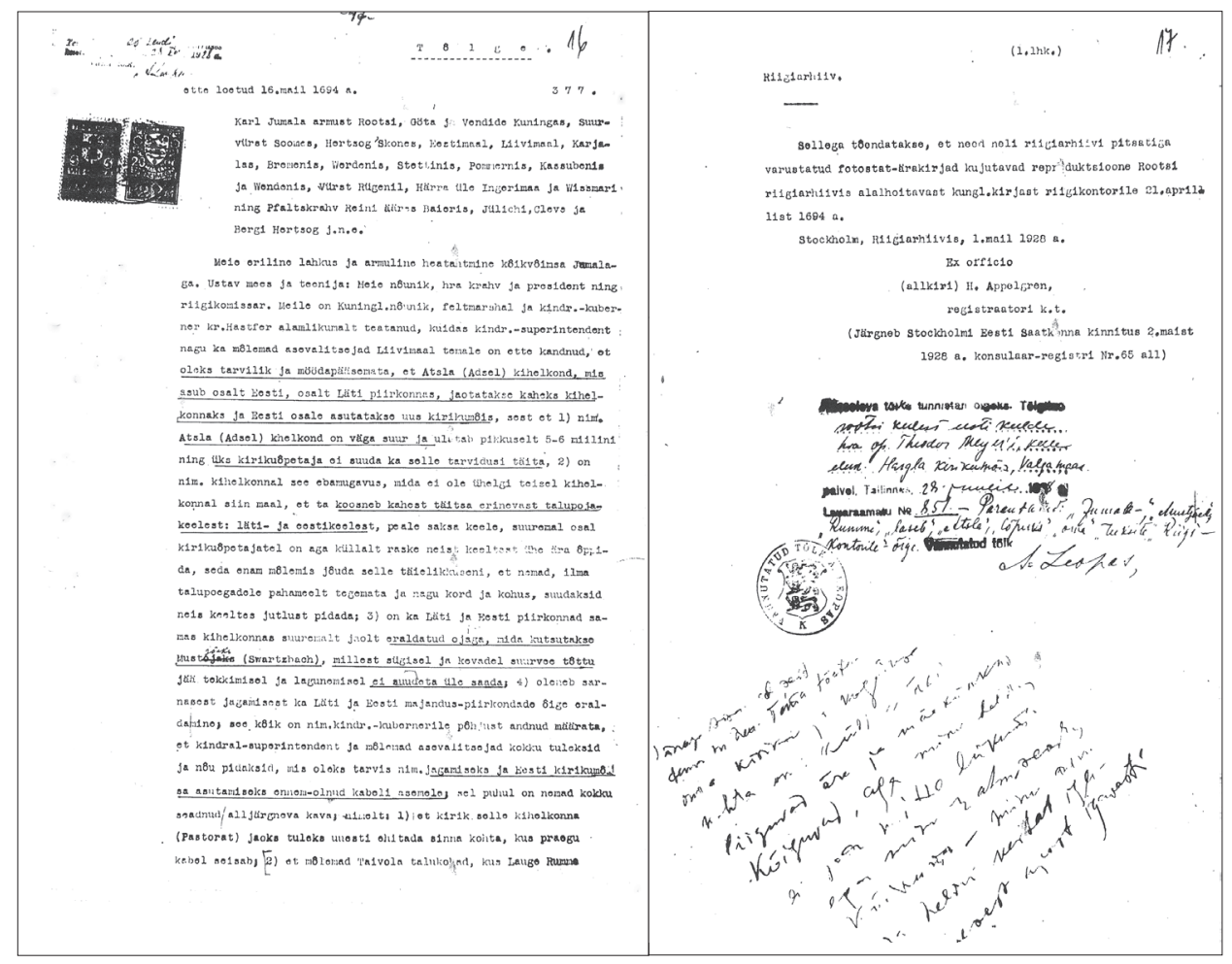

Joonis 1. Koopia Karl XI korralduse tõlkest eesti keelde. 16. mail 1694. aastal antud korraldusega asutati Mustjõe Eesti-poolsele alale uus kirikukihelkond - Hargla.

konna elulaadi, kultuuri, ainelist ja vaimset pärandit. Enne iseseisvate riikide tekkimist oli see piirkond Liivimaa kubermangu eesti ja läti keele kokkupuuteala. Kirikukihelkondlik jaotus rahvuste järgi tekkis siin alles 17. sajandi lõpus.

Suurust on kihelkonnal umbes 350 ruutkilomeetrit, laiust kitsamas kohas ca 4 km ja laiemas kuni $15 \mathrm{~km}$. Kihelkonna lounapiir (umbes $35 \mathrm{~km}$ ) on samaaegselt ka Eesti Vabariigi lõunapiir. Hargla kihelkonna Naha küla (samanimeline küla asub ka Räpina kihelkonnas, mis kultuurikirjutistes on põhjustanud mõnikord teatavat segadust) on Eesti kõige lõunapoolsem punkt.

Tänapäeval jaguneb kihelkonna territoorium Valga ja Võru maakonna vahel ligikaudu võrdselt. Kihelkonnakeskus Hargla asub Valga maakonnas, kihelkonna Taheva valla osa ulatub põhjaosas paari küla ulatuses ka Karula kihelkonna alale. Lisaks arvukatele - ja rahvapärimuses kohalugude ja uskumusteadete kaudu soliidselt esindatud - jõgedele (Mustjõgi, Koiva, Peetri ja Vaidva jõgi) on kihelkond ka üks metsarikkamaid - Taheva valla pindalast 

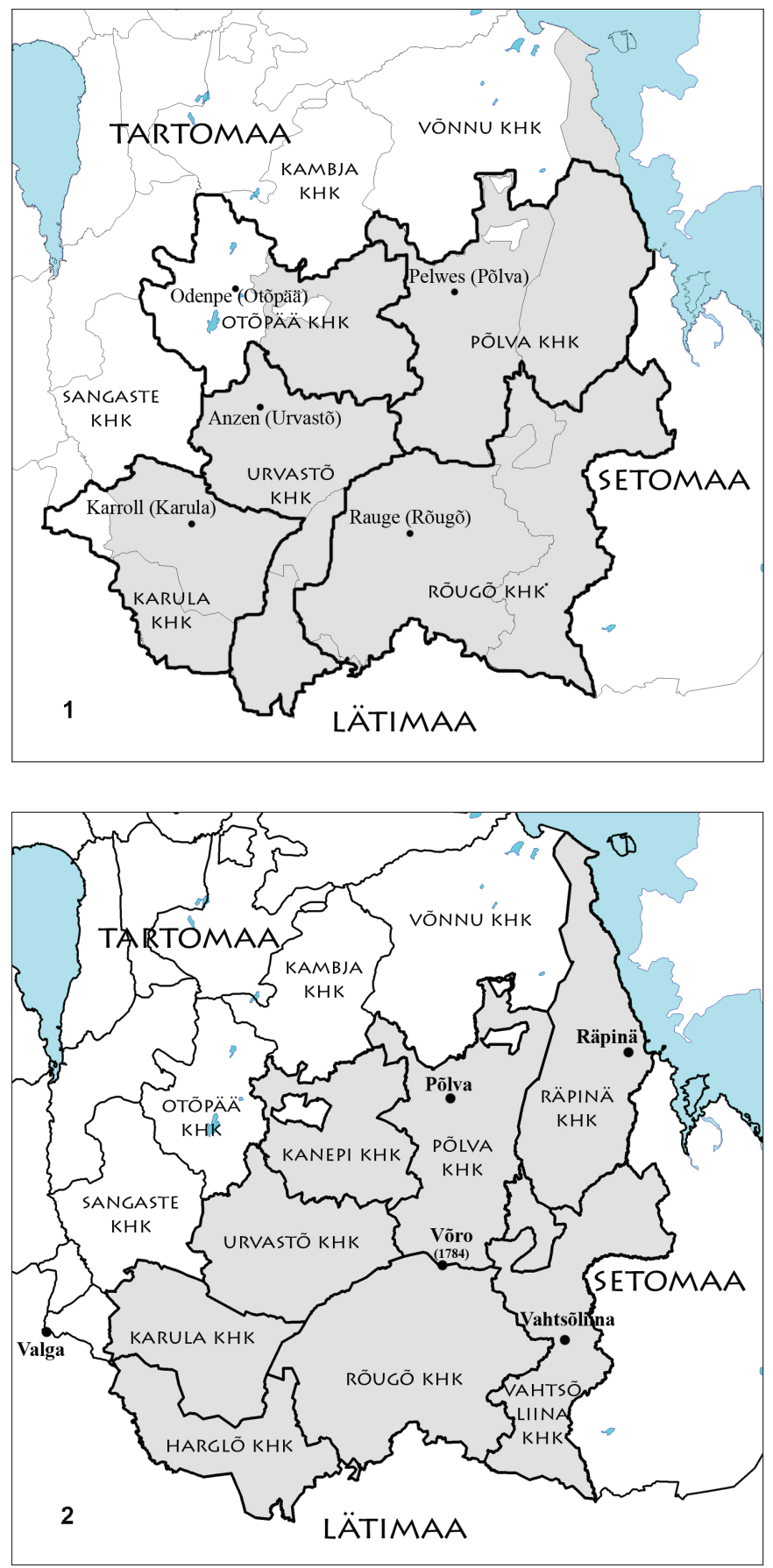

Joonis 2. Kaardid: 1 Harglata, 2 Harglaga. Kaartide autorid Arvis Kiristaja ja Evar Saar. 


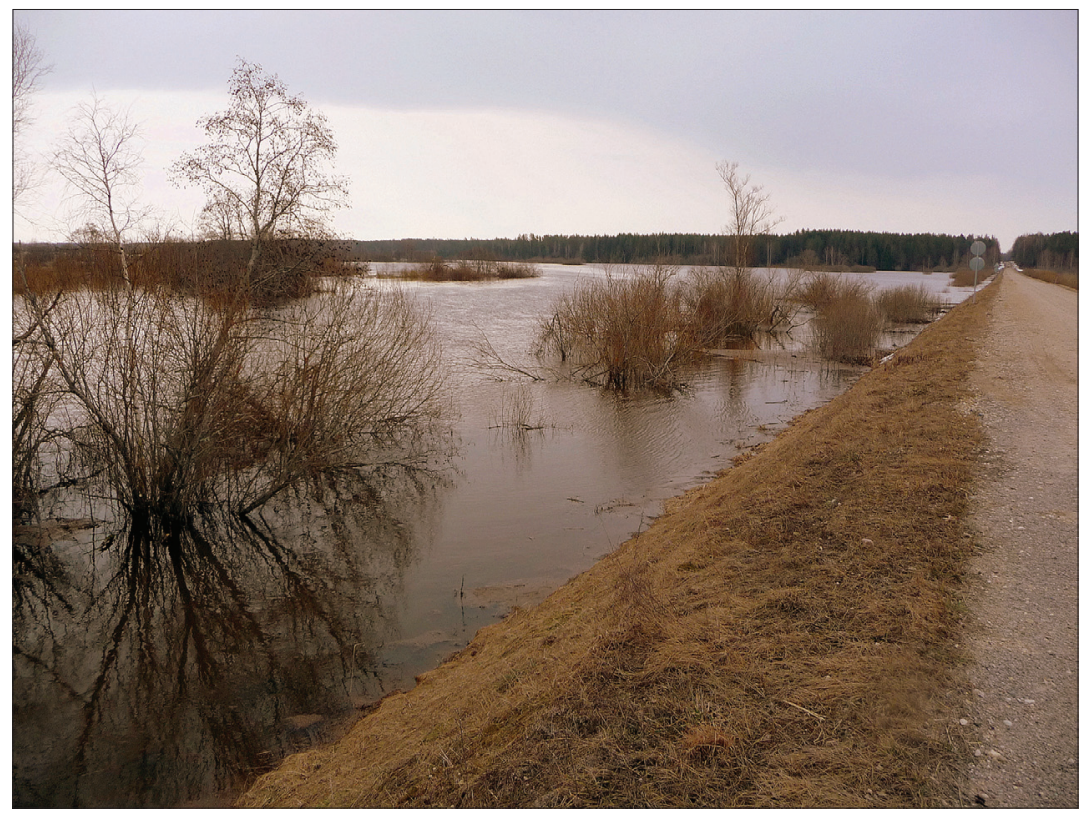

Foto 2. Üleujutus kevadisel Mustjõel. Fotol on näha on endise Valga-Ape kitsarööpmelise raudtee tamm, praegu kasutusel sõiduteena. Marju Kõivupuu foto aprill 2009.

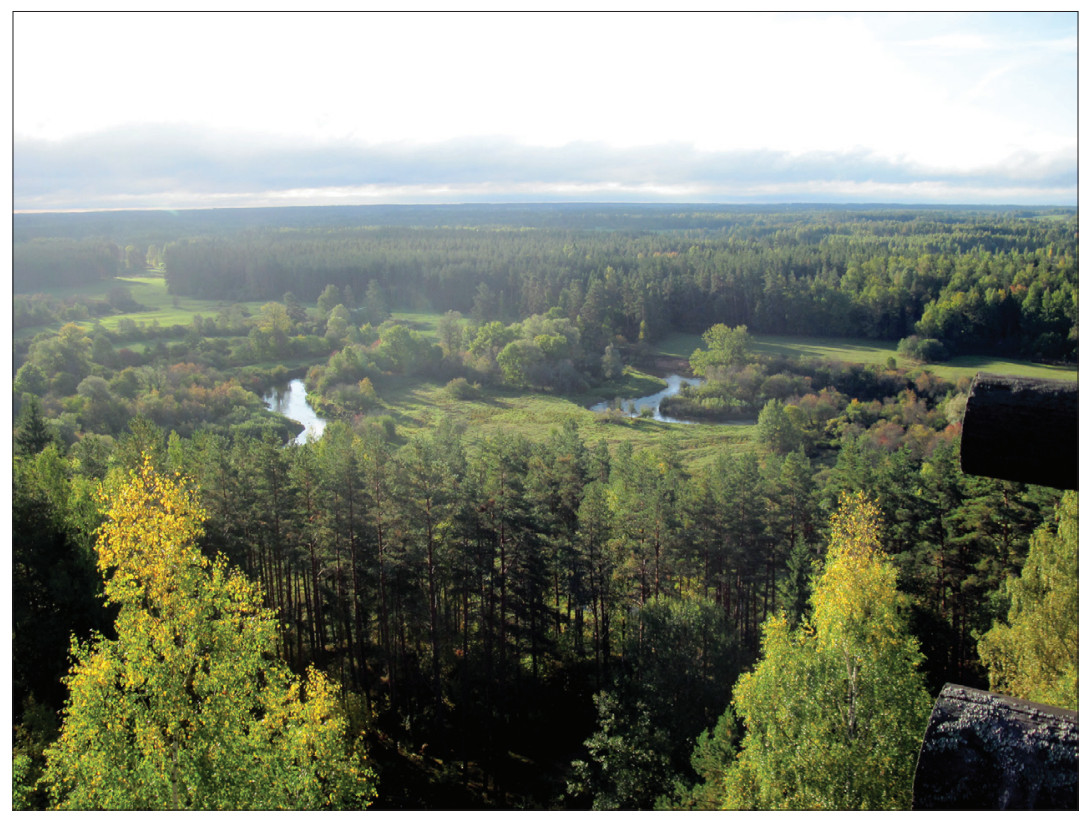

Foto 3. Vaade Tellingumäe vaatetornist kihelkonnale ja Mustjõele koos vanajõgedega. Marju Kõivupuu foto 2013. 
$67 \%$ ja Mõniste valla pindalast $57 \%$ on kaetud metsaga. Eraldi väärib märkimist seegi, et suurema osa valla territooriumist hõlmavad looduskaitsealad. Tähtsaim ühendusmagistraal on valda läbiv Valga-Võru maantee. Valla keskus asub maakonnakeskusest Valgast $25 \mathrm{~km}$ kaugusel, naabermaakonna keskusest Võrust 57 km kaugusel ja Tallinnast 270 km kaugusel.

Taheva valla territooriumil paikneb 13 küla, elanike arv 1. jaanuaril 2012 oli 816. Suuremad külad on 1. jaanuari 2010. aasta seisuga Hargla 223 elanikuga, Koikküla 209 elanikuga, Laanemetsa 93 elanikuga ja Taheva 79 elanikuga. Tõrvase külas, kus käisin välitöid tegemas 1990. aastatel, ei ela aastast 2010 enam ühtegi inimest. Elanike arv piirkonnas on viimasel kümnel aastal pidevalt langenud nii negatiivse loomuliku kui mehaanilise iibe tõttu (http://www. taheva.ee/ - 26. september 2012).

Taheva nimi on kaasaegne vaste kohanimele Taiwola, mida 17. sajandi keskel tunti Liivimaal mõisana ja mis ühendas Gauijena, Taheva, Karula, Antsla ja Otepää mõisate ketti. Esimesed kaardimaterjalid Taheva vallas eestlaste poolt mõisatelt päriseks ostetud maade kohta pärinevad 1867. aastast. Algselt moodustati Hargla kirikumõisast ja Taheva mõisast Taheva vald ning Laanemetsa mõisast ja Koikküla mõisast Laanemetsa vald, kuid hiljem liideti need kaks valda üheks Taheva vallaks.

Mõniste (Mendis, Monaste) ümbrus on piirkonna vanim asustuskeskus, kirjalik esmamainimine pärineb seni teadaolevalt aastast 1386 . Siit on leitud tulekivitükke ja mitu kivikirvest. Omapäraseid ja Eestis üks väheseid leide jääajaeelsest loomariigist on mõned siit päevavalgele tulnud mammutiluud (Lõugas \& Selirand 1989: 372).

1948. aastal asutas tuntud kodu-uurija Alfred Lepp Kuutsile koduloomuuseumi, esimese vabaõhumuuseumi kogu Eestis ${ }^{5}$. Tema eestvõttel toimus 1956. aastal Mõniste külanõukogus koosolek, kus piirkonna arheoloogiamälestised (matusepaigad, kabeliasemed jms) anti kohalike usaldusmeeste hoole alla, et tagada nende säilimine ka tulevastele põlvedele. Toonased usaldusisikud on nüüdseks manalamehed, aga loend on usaldusväärne informatsiooniallikas tänastele arheoloogidele ning teistele huvilistele. Arvestades ajaloolist konteksti oli selline lähenemine maastiku- ja kultuuripärandile omas ajas vaieldamatult eesrindlik.

Mõniste valda läbib viis jõge: Mustjõgi, Peetri jõgi, Vaidva jõgi, Ahelo jõgi ja Peeli jõgi. Vallas on kolm paisjärve: Mõniste külas, Vastse-Roosa külas ja Veskijärv Saru külas ning ainult üks looduslik järv - Ubajärv, mis kuulub lahustükina Karula rahvuspargi koosseisu. Suuremad külad Mõniste vallas on Saru, Mõniste ja Kuutsi. Mõniste vald oli vald Võrumaal ka aastail 1939-1950. Mõniste vallas elas 1. jaanuaril 2012. aastal 502 meest ja 472 naist, kokku 974 inimest (http://www.moniste.ee/ - 20. september 2012). 


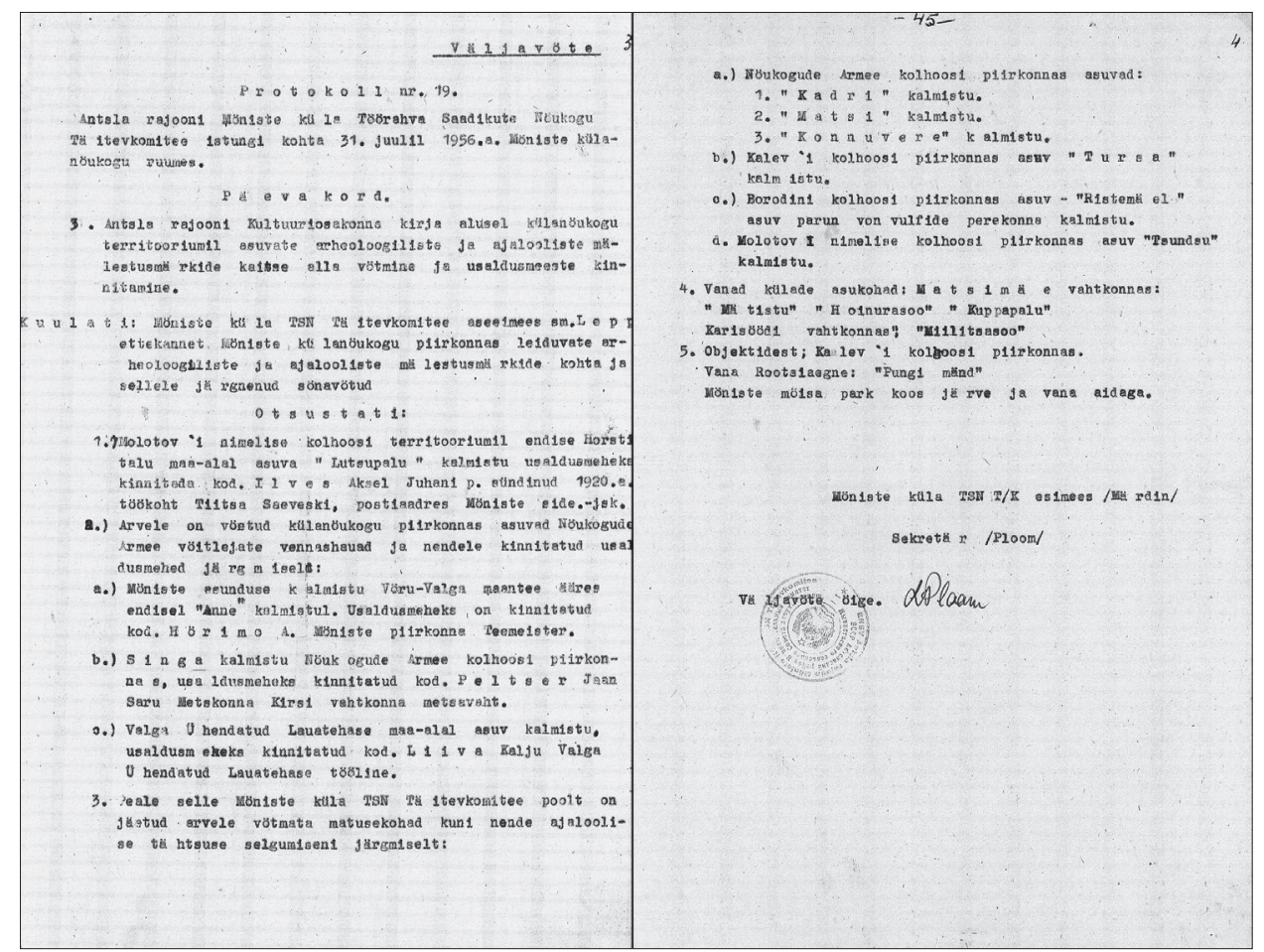

Joonis 3. Koopia 1956. aasta koosoleku protokolli väljavõttest. Sellel koosolekul otsustati võtta kaitse alla Mõniste arheoloogilised ja ajaloolised mälestusmärgid.

\section{Matusepaigad, kiriku- ja kabeliasemed}

Suhteliselt hästi on praegusajal Hargla kihelkonna (põlis)elanike mälus säilinud esiajaloolised matmispaigad ning kesk- ja varauusaegsed kiriku- või kabeliasemed ning arvatavalt nende juurde kuulunud matusepaigad. Ilmselt seetõttu, et muist neist on ka tähistatud ja neist on ajakirjanduses korduvalt kirjutatud. Neist kahte, suhteliselt lähestikku asuvat Anne ja Katri kabeliaset osatakse ka tänapäeval näidata ja neist ka lugusid kõnelda. Anne kalmistu ja kabeliase on võetud muinsuskaitse alla.

Mitmeid muistse kiriku varemeid või asemeid tunneme Saru ja Mõniste alalt, need on need veikesed puukirikukesed, mes muiste katolikul ajal ehitati üle maa ja neil igaühel oli mõni katoliku pühaku nimi. Mõniste mõisa Paju kõrtsi taga Anne kirik koos surnuaiaga, kus tänapäev on punaarmeelaste matus, maantee ääres, just vana surnuaia 
Joonis 4. Väljavõte 18. aprilli 1939. a ajalehest Postimees.

kohal teeääres. Iidne legend kõneleb, et seal on olnud ka rahakelder maa sees vana surnuaia taga, kus mustad mehikesed jaaniööl enda raha kuivatasid, pikad hargid käes, kust mõnele mõistlikule möödaminejale ka tuliseid süsi põlle visati, mis pärast kuldrahaks muutus. Rahakeldri võti on olnud Mõniste mõisas. Kui vana von Vulf enne surma lolliks jäi, siis tema on lasknud tolle võtme mõisa järve heita, see on olnud nii suur, et kaks toapoissi ei ole kudagi jõudnud kanda (RKM II 247, 387/8 < Hargla khk. < Mõniste - Minna Kokk < Minna Kokk, s. 1892, oma mälestuste järgi (1967)).

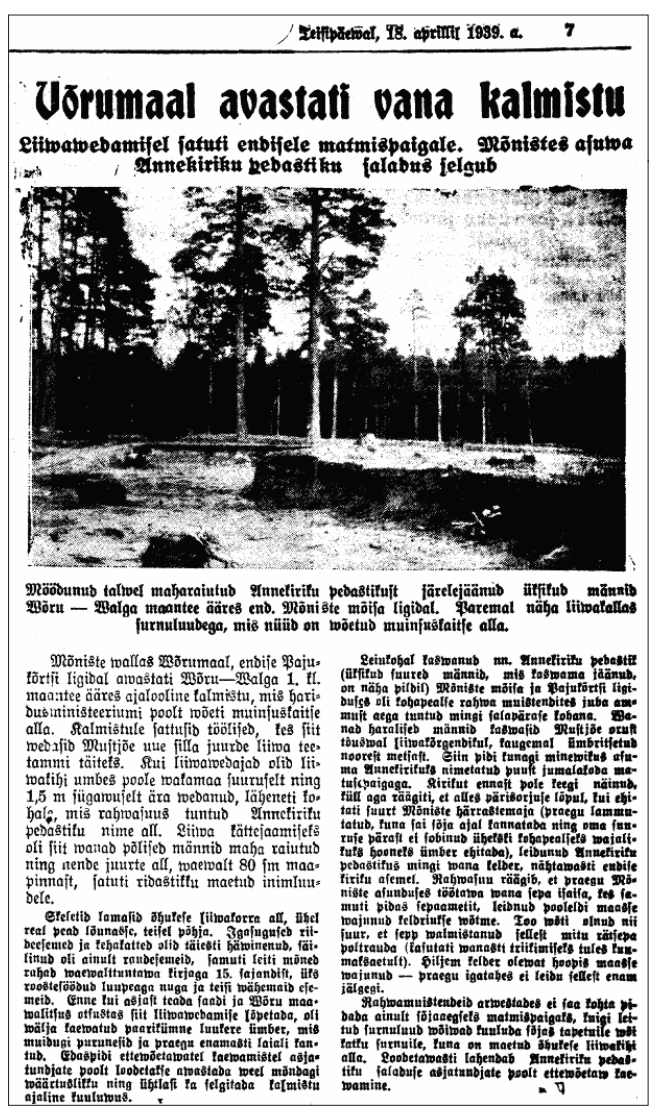

Mõniste vallas end. Mõniste mõisa maal, praegu riigimetsas asub nn. Anne kiriku pedajas. Kohta katab õre männimets ja ta asub umbes 600 meetert Mõniste mõisast Võrusse viiva maantee ääres. Varem olla siit kohalt leitud inimeste luid, millest rahvas arvab, et siin olnud rootsiaegne matmispaik ja isegi kirik Anne nimeline. Asuvat siin kuskil ka kullakammer, mille võti olla leitud aastat 15 tagasi, mis olla viidud mõisahärrale. Võti olnud kaunis suur, umbes 40-50 cm. pikk (http://www.folklore.ee/pubte/ ajaloolist/hargla/hargla.html).

Pärast Teist maailmasõda püstitati matusepaiga vahetusse naabrusse mälestusmärk nõukogude sõjameestele, mille juures korraldati nõukogulikke rituaale (nt 9. mai tähistamine, pioneeriks või komnooreks vastuvõtmine jne). Uue Valga-Võru maantee rajamise järel jäi koht suurteest kõrvale ning taasiseseisvumisperioodil kasvas võssa, juurdepääs oli raskendatud. Nüüdseks on ümbrus korrastatud, kuid suunaviit arheloogiamälestisele uuelt Valga-Võru maanteelt 
puudub. Arvatava matusepaiga ja kabeliaseme kohal kasvab kaks vana mändi, need ei eristu metsast, mis on peale kasvanud pärast Teist maailmasõda. Praegune maaomanik teab koha väärtust ja on vajadusel koostöövalmis, kui peaks olema vaja seal läbi viia uurimistegevust.

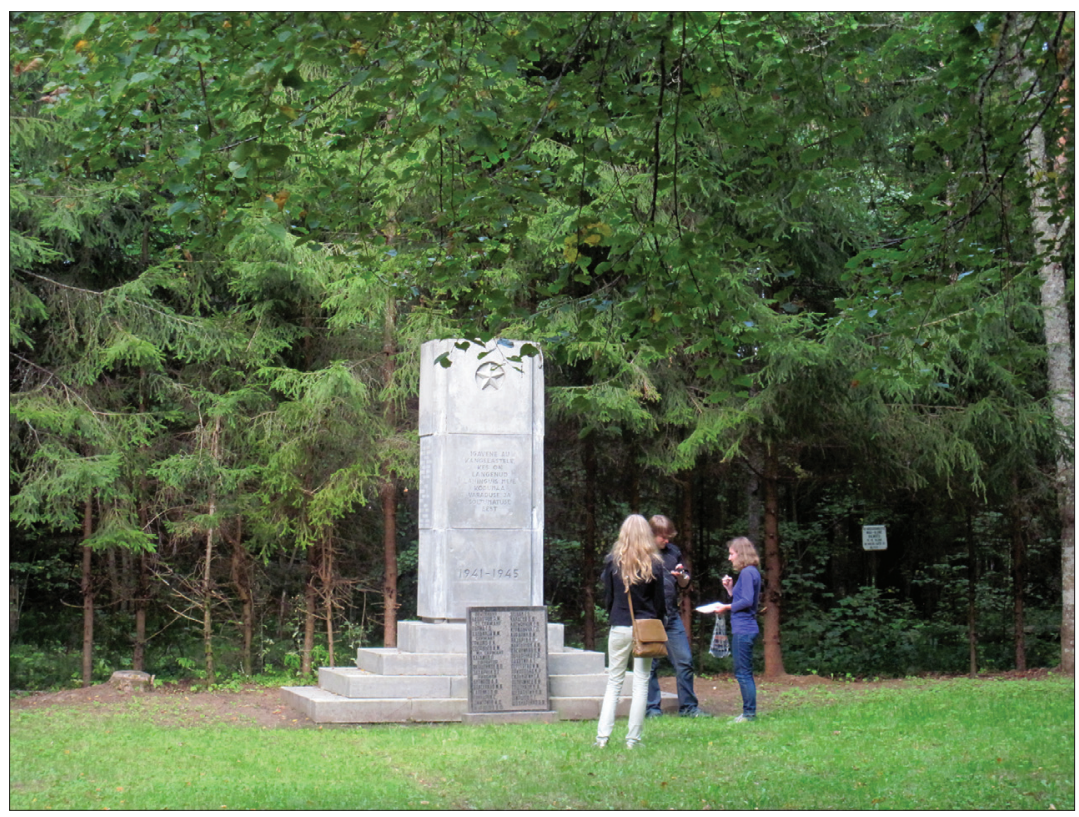

Foto 4. Anne kabeliasemel ja matusepaigas. GPS-punkti võtavad Kaarel Kõivupuu, Kristiina Tiideberg ja Anneliis Peterson. Marju Kõivupuu foto 2013.

Kohalikus pärimuses hästi tuntud Katri (ka Kadri või Katre) kõivistik ja kirikuase asub Mõniste ja Saru küla piiril, praeguse Võru -Valga maanteelt sadakond meetrit Mustjõe poole. Teisele poole maanteed viib Saru-Mäepõru teeots. Kunagine tee, mida oskavad umbkaudu näidata vaid kohalikud, on läinud väidetava kalmistu ja kabeliaseme juurest mööda. Kalmistu- ja kabeliase asub jõe poolt vaadates suhteliselt kõrgemal kohal, kunagise tee jäljed on tänasel maastikul vaevalt aimatavad.

Saru vallas Kallaste külas Osvald Kõivi ja Hendrik Rõõmuse krundil (piiri pääl) on leitud inimeste luid ja vanu rahu, mille kohta teatakse, et üks raha olnud pärit 1400. a. [vrd paiga esmamainime 1386 - M. K.]. Matmispaigast 90-95 meetert eemal näidatakse mingisugust arvatava kirikuaset ja sellest veel 25 meetert eemal asub n.n. Katri kiriku kõivik (nimi kõivikule on tulnud vist kirikust). (EKLA, F 199, m 28 Hargla: ajalooline traditsioon.) 
Endise Mäe-Matsi talu maa peal (end. Saru küla, Nõuk. Armee kolhoos) arvatakse olevat Põhjasõja aegne kalmistu. (ERM EA 57: 167, T. Paevere (Habicht) < Bruno Hanimägi, 55 a., Antsla raj., Mõniste k/n, Nõuk. Armee kolhoos (1955).)

Seal, kus praegu on kolhoosi uus laut, seda kohta kutsuti Katri kiriku kõivist. Seal kasvasid kõod. Seal olevat rootsi aeg sunuaed olnud. Kolhoosi laudast mäe pool on suur kivi. On ära keelatud, et ei tohi lõhkuda, et seal on rootsikeelsed märgid peal. Rootsi märk on peal, kui rootsi sõda siit läbi läks, on tehtud. (ERM EA 57: 193, T. Paevere (Habicht) < Juhan Kolk, 64 a., Antsla raj., Mõniste k/n, Nõuk. Armee kolhoos, Ala-Tamme talu, end. Saru küla (1955).)

Saru vallas Leeguste (om. Johan Paag) [õige on ilmselt Johan Pang - M. K.] ja Matsi (om. Gustav Rebane) talude piiril arvatakse olnud olevat endine matmispaik. Koht on liivane ja ümbruses ainukene, kus liiv asub, sellepärast on ta nü̈̈d kartuliaukudega läbi kaevatud. Siit on leitud umbes 40-50 a. tagasi mitmesuguseid rahu, sõrmuseid ja inimeste luid. Samuti on nähtavale tulnud mingisugune kivine aluspõhi. Kivid on olnud mehe kandejõu suurused ja nü̈̈d ära veetud ehitusteks. Rahvas räägib, et siia tahetud ehitada kirikut, alus tehtud valmis, kuid siis jäetud pooleli teadmatul põhjusel. (EKLA, F 199, m 28 Hargla: ajalooline traditsioon.)

Pärast Teist maailmasõda ehitati arvatavale kalmistule ja kabeliasemele Mõniste kolhoosi/sovhoosi karjalaudad, 1960. aastatel lehmalaudad, hiljem sigala ja kaalukoda. 1930. aastatel sündinud mäletavad, et nende lapsepõlves (kuid ka hiljem) olnud seal veel mõned hauasambad või nende tükid. Kuhu need on saanud, täpselt ei teata. Kohta kutsuti rahvasuus kolhoosiajal ka "Katri kõivistu laudad" või "Katri kiriku laudad", ning majandi lehmakarja, kes käisid Saru-Mäepõrru karjamaadele, kutsuti Katri kiriku karjaks. Kohalik rahvas teab kõnelda ka pärast Teist maailmasõda tegutsenud aardeotsijatest, kes on kalmistult püüdnud leida nn Rootsiaegset kulda ja muud varandust. Praeguseks on ka lehmalaudad hävinud, säilinud on vaid 1970. aastal EÜE Lõunaregiooni Varstu rühma ehitatud kaalukoda ning sigala tarvis ehitatud majandushooned. Millist ajaloolist informatsiooni koht tegelikult sisaldab, ei ole võimalik folkloristikas praktiseeritavate meetoditega kindlaks teha. 


\section{Horsti- või Lutsupalu ohvrikivi (ehk Kuutsi "tegutsev" ohvrikivi) ja Tinnüsmatus}

Üks tänaseni aktiivselt tegutsev ohvrikivi - umbes täpselt sellises sõnastuses meid selle, arvatavalt II aastatuhandest pärit pühakivi juurde juhatati - asub samuti kunagise matmispaiga (Tinnüsmatus) ning Antoniusele (Tõnis, Tinnüs) pühendatud kunagise kabeli asukohas.

Mõniste vallas Horsti talu omanik Andres Lindenberg. Kõrgendikul, metsastunud karjamaal asub end. matmispaik. Koht on liivane ja 1922. a. suvel on siit liiva veetud, kuid midagi iseäralikku pole päevavalgele kerkinud, ent umbes 30 aastat tagasi on siin väljakaevamisi teinud Viljandimaa mees (nime ei teata), kes on ühest kohast leidnud kivikirve ja ka inimeste luid, kuna teisest kohast inimese luukere istuvas asendis, mille juures on olnud ka pronks rahu ja sõlg. Võimalik, et kohta omal ajal on tarvitatud ka ohvrimäeks, sest rahvas nimetab teda nõnda. Räägitakse ka, et selle mäe ligidal olevat asunud n.n. Tiinuse kirik [õige peaks olema Tinnüse, ilmselt ei ole koguja olnud võrukeelne inimene - M. K.], millist kohta praegu küll näidatakse, kuid midagi ei tunne. (EKLA, F 199, m 28 Hargla: ajalooline traditsioon.)

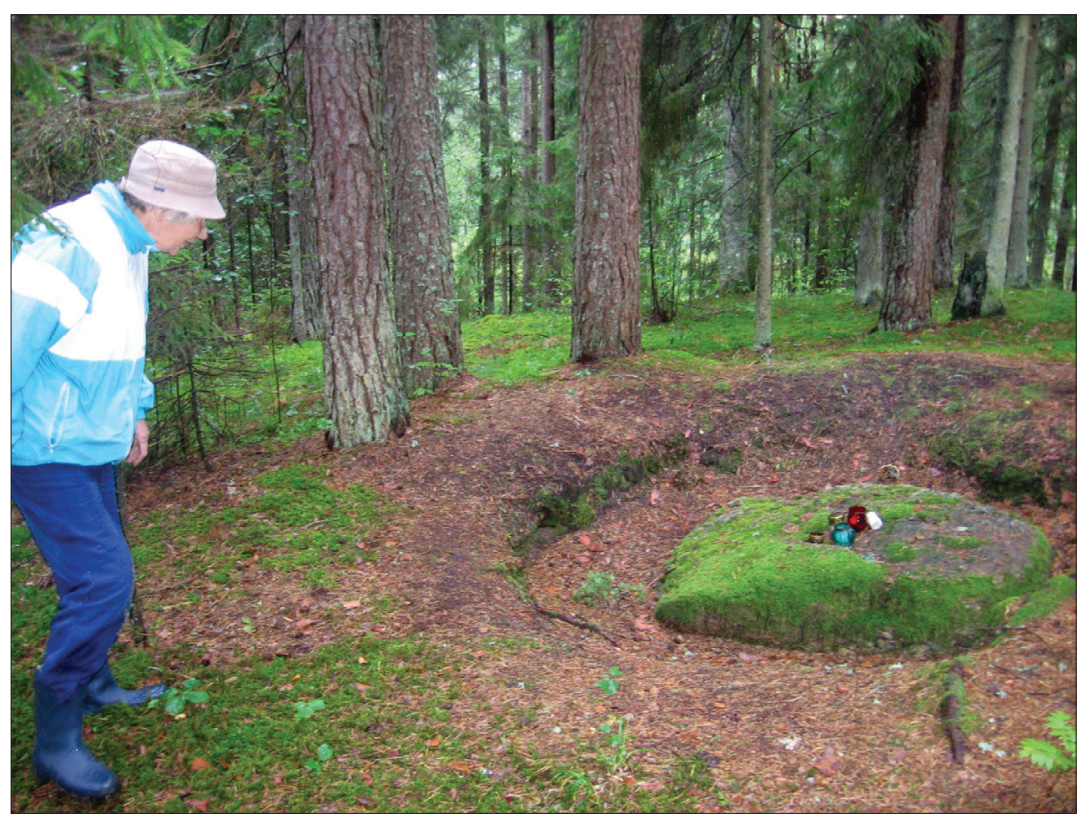

Foto 5. Antonina (Tooni) Pettai näitab “tegutsevat” ohvrikivi. Marju Kõivupuu foto 2012. 
Tegemist on nn kompleksse pärimusmälestisega, kus asub kivi (pühakivi, ohvrikivi); vana matusepaik ja arvatavalt Antoniusele (Tõnisele, Tinnüsele) pühendatud kabeli ase. Ohvrikivi kuulub II aastatuhandesse. Kivi on kaitse all alates 1964. aastast, mil see kaevati maa seest välja. On tähelepanuväärne, et vanemates muisuskaitseregistrites on kivi ja kabeliaseme asukohaks märgitud Rõuge kihelkond.

Kohaliku ajalooõpetaja ja kodu-uurija Aili Paeglise sõnul käib ohvrikivi juures ja selle eest hoolitseb peamiselt kohalik koduloohuviline Antonina (Tooni) Pettai. Kohalikke kooliõpilasi viiakse kivi juurde näiteks hingedepäeva aegu, mil õpetaja räägib seal lastele vanadest rahvakommetest. Pühakivi juures käiakse ka teiste koolikalendriga seotud tähtpäevade puhul, kuna seal ligiduses asus praeguse Kuutsi põhikooli "eelkäija", omaaegne Lutsupalu kool. ${ }^{6}$ Millal sellistele traditsioonidele alus pandi, täpselt ei teata, arvatavasti 1980. aastatel.

Sama metsatee äärde, mis viib tinnüsmatuse ja pühakivi juurde, asub söll ehk sulglohk - Silmussoot (Silmussoot, -soodi), tuntud ka kui Tinuse suut, Tinussuut (Antoniuse ehk Tõnise soot ${ }^{7}$ ). Silmussoot on tänaseks maastikul raskesti aimatav, selle peal kasvab istutatud okaspuunoorendik. Inimesed selle paiga kohta tänapäeval enam lugusid jutustada ei oska. 20. sajandi esimesest poolest pärit üleskirjutuste kohaselt on selles paigas kogetud üleloomulikku.

\section{Ristipuumetsad ja üksikud ristipuud}

Hargla kihelkonna elava usundilise ja kombekäitumisliku praktika (matusekombestik) hulka kuulub jätkuvalt ristipuude traditsioon, seda nii Mõniste kui ka Taheva vallas (vt ka Kõivupuu 2009). Viimased matused, kus ka rist lõigatud, pärinevad aastast 2013. Puusse mäletusristi lõikamise kommet siinkandis ohustab ainult ja ainult külade tühjenemine nii demograafilise situatsiooni tõttu (elanikkonna vananemine, negatiivne iive) kui ka mehaanilise iibe tõttu. 2010. aastal lõigati Sarupallu viimaste Tõrvase küla vanade inimeste ristid, sealtmaalt on küla tühi. Hargla kihelkonna matustel järgitakse veel traditsioonilisi kombeid - surnuvalvamine, kirstu- (isiklikud emotsionaalse väärtusega esemed) ja hauapanuseid (kirstu katmine omakootud tekiga), mälestusristi puusse lõikamine, paljukordne toidupakkumine, esimesele vastutulijale anni andmine jne (vt ka Kõivupuu 2009).

Kuigi Kagu-Eesti ühe suurima - Saru-Hargla ristipalo näol ${ }^{8}$ on tegemist puistuga, mis on juba saavutanud lageraiet lubava vanuse, tuleb pärandkultuuriobjekti kaitsmise ja säilitamise seisukohast jätta need pühad metsad raietest puutumata. Kuna tegemist on männikutega, võivad need ristimetsad mändide pikaealisuse tõttu säilida looduslikult veel sajandeid. Ka Saru lauatehase juures säilitatud väga kitsas mändide riba on võimeline tõenäoliselt veel aastasadu 
püsima elujõulisena, sest männid on suhteliselt tormikindlad isegi üksikuna, seda kindlamalt puuderühmana.

\section{Hargla kihelkonna püha pettai}

Harglõ tii veeren ollõv üts sä̈̈räne petäi, kon elläv seen puugi. Tuud ei tohtiv kiiäki maha raku. (ERA II 243, 731 (44) < Hargla khk., Mõniste v., Tursa t. - Lehte Kuus, Vastse-Roosa algkooli õpilane < Miili Must, 59 a. (1939).)

Marju Kõivupuu 1990. aasta välitööde päevik ja hilisemad tähelepanekud kinnitavad, et kohalikud inimesed teavad - see on vana pühapuu. Erilisi uskumusi kõnesoleva puuga ei teata, küll on räägitud puu kohta varavedaja-muistendeid ehk puugijutte. 2000. aastatel oli mõnikord kombeks käia laulatuselt tulles puu juures ja siduda sinna ohvripaelake. Viimased 20 aastat olen aastas vähemalt korra või kaks käinud ohvripuu juures, ohvriande vms ei ole täheldanud.

Kas Hargla omaaegsete kirikuõpetajate poolt talletatud siinse rahva ohverdamiskommete kirjeldusi saab siduda just konkreetselt selle puuga, on iseküsimus. Osundatav tekst, mille sihtrühmaks on matkajad ja turistid, on ilmselt

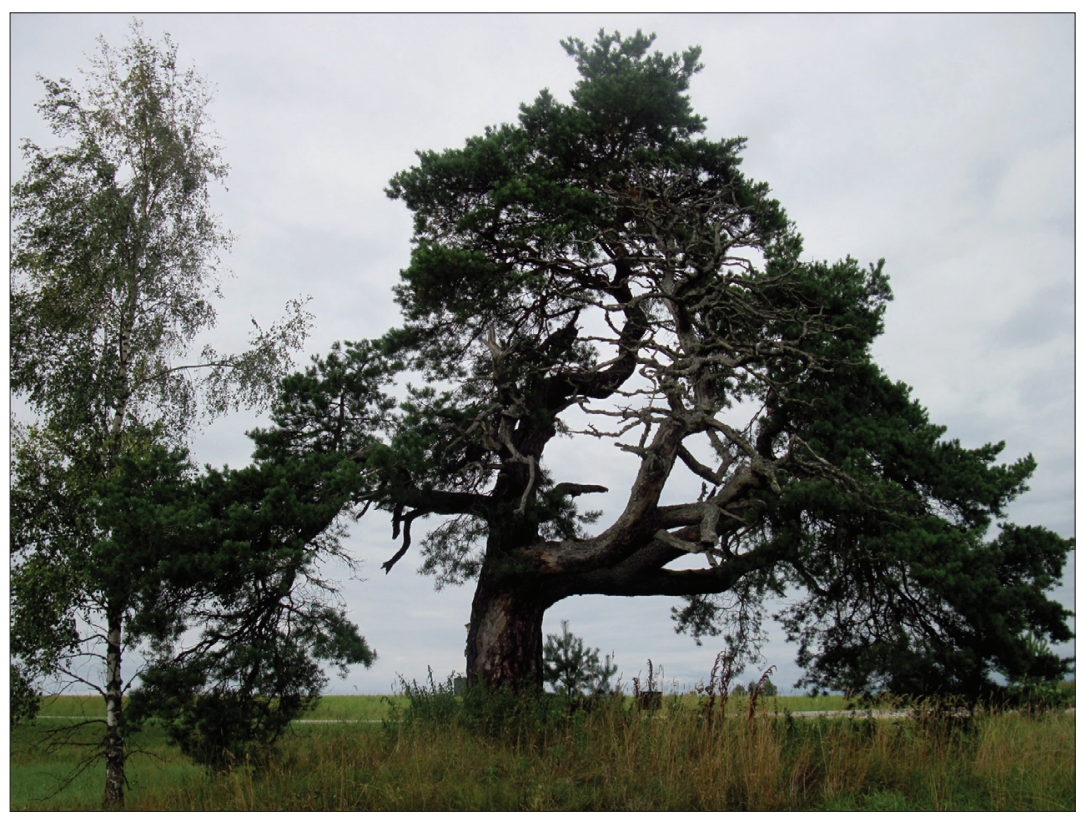

Foto 6. Hargla püha pedajas. Marju Kõivupuu foto 2012. 
kompilatsioon teemakohastest tekstidest, mida kõlbab kasutada peaaegu kõikide pühapuude kohta. Käesoleval juhul on peetud silmas Hargla püha pedajat:

Kui kätte jõudis neljapäeva õhtu, mindi puu alla paluma ja ohverdama. Ohvripuu oli nii püha, et keegi ei julgenud oksagi murda, sest arvati, et murdjal loom sureb või mõni muu õnnetus juhtub. Puud pidi vähemalt kord aastas loomaverega kastma, peale selle pidi veel tapetud looma värske liha leent puu juurele valama, et loomad jõudsalt kosuksid ja sigiksid (http://www.suveseiklus.ee/?pagename=2004-3 -27. november 2012).

\section{Pärimuse konstrueerimine maastikul}

Pärandkultuuri objektide otsimine, inventeerimine ja maastikule märkimine on Eestis hoogustunud viimasel aastakümnel Riigimetsa Majandamise Keskuse (RMK) eestvõttel ja rahastamisel arvukate kohalike korrespondentide ja vabatahtlike abiga. Pärandkultuuri mõiste on RMK defineerinud üpris laialivalguvalt, viimasest tuleneb ilmselt ka ambitsioonikas ülesandepüstitus:

Pärandkultuur on oluline osa meie kultuurist, tükike rahvuslikust identiteedist. Selleks, et unustuse hõlma vajunud kultuurimärgid uuesti tähelepanu alla tuua, on RMK ette võtnud ulatusliku pärandkultuuri inventeerimise. Eesmärgiks on kaardistada kogu Eesti pärandkultuur, sõltumata selle maa-ja omandivormist (RMK kodulehekülg: http://www. $\mathrm{rmk}$. ee/teemad/parandkultuur - 6. jaanuar 2012).

Lisaks inimloodud pärandkultuuriobjektidele (ehitised või ehitiste varemed ja muud inimtegevuse jäljed maastikus) on RMK poolt tähistamisväärseks peetud ka üksikuid pühaks peetud või tänaseni pühaks peetavaid loodusobjekte (puid, kive, allikaid). Iga konkreetse objekti kohta käiva teabe kvaliteet ja usaldusväärsus näib RMK paigaldatud teabetahvlitel olevat otseses sõltuvuses kas veebipõhiselt kergestileitavast informatsioonist ühe või teise pühapaiga kohta või kohalike korrespondentide ja vabatahtlike teadmisest.

RMK poolt tähistatud Koiva pärandkultuuri rajal fikseeritud pärimusmälestised (üks pühakivi ja pühapuu) kandsid asjatundmatuse ja pealiskaudse suhtumise märke. Teabetahvli info oli väär ja eksitav - pühaks peetud männi kohta käiv foto oli n-ö illustreeriv (pildil oli kujutatud Põhja-Eestist Lahemaalt pärit Ilumäe hiieniinepuud, pühakivi juurde käiv foto on hangitud internetist ning fotol kujutatud pühakivi sarnaneb Lääne-Eestis leiduvatele) ning tekstid ei kajastanud kohalikku pärimust. Kummagi objekti kohta ei ole suulist pärimust kirja pandud, kuigi mõlemad on võetud looduskaitse alla. 

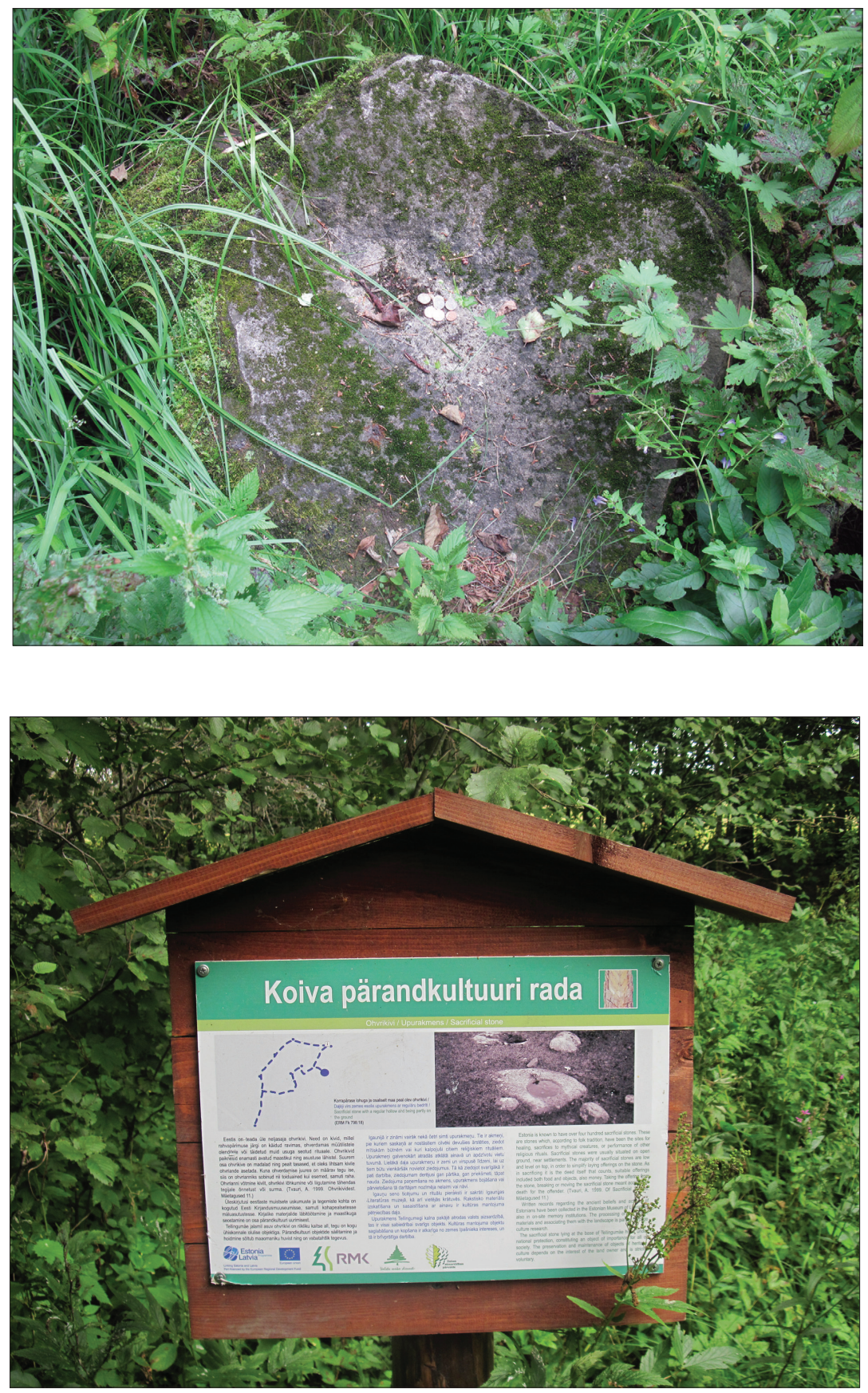

Fotod 7. ja 8. Eksitajad maastikul: Tellingumäe püha kivi ja tema kohta käiv infotahvel. Marju Kõivupuu fotod 2012. 


\section{Kokkuvõte}

Maastik on alati olnud dünaamiline, muutlik ja kaduv, ning ta jääb selliseks nii kujutlustes kui ka materiaalse keskkonna poolest. Muutumise üleelanud tunnismärgid ja mõistmine on mineviku-või maastiku-uurimise sügavaim huvi ja eesmärk (KrEm 2003: 16).

Kohapärimuse säilitamist toetava tegurina domineerib Hargla kihelkonnas alates sõjajärgsetest aastatest (1950. aastate lõpust) väga tugev kodu-uurimise traditsioon, mis omakorda on kinnistanud kohalike inimeste mällu tähenduslikud paigad ja nendega seotud pärimuse. Maastikutundmist ning huvi koduloo ja kohapärimuse vastu on soodustanud nn Võru liikumine (1980. aastate lõpust) koos kodulugu populariseerivate trükistega. ${ }^{9}$ Usundilisi jutte või teateid üleloomuliku avaldumise kohta erilistes paikades (kabeliasemed, ristimetsad, puugipedajad) ei õnnestunud 2012. aasta välitöödel (enam) kirja panna.

17 inventeeritavast objektist (kivid, puud, esiajaloolised matusepaigad ja katoliku-aegsed kabelid) õnnestus peaaegu kõik üles leida, seda küll suuresti tänu päritolukeskkonnast tulenevale ja varasemate välitööde (Hargla kihelkonnas vastavalt 1988, 1989, 1990) kogemustele. Tehtud intervjuude ja küsitluste põhjal leidis osaliselt kinnitust seisukoht, et ka suulise mälu puhul tuleb olla allikakriitiline ja mõõdukalt skeptiline - näiteks nn Anne kabeliase aeti segamini omaagse Anne teivasjaamaga (mis omakorda on saanud nime Vana-Antsla karjamõisa ja sellenimelise väikese küla järgi) Valga-Antsla raudteel, mis jääb kabeliasemest linnulennul umbes 15-20 km kaugusele Karula kihelkonda jne.

Hargla kihelkonna kohapärimusele ei näi olevat tunnuslik haiguste puhul erilistest (püha)paikadest abi otsimine, välja arvatud arvatavalt surnute poolt saadetud tervisehädad, mispuhul otsiti abi ristipuude juurest, tuues puude alt tervendamiseks kaasa mulda või liiva (vt Kõivupuu 2009). Üheks põhjuseks võib arvata, et kuna piirkonnas tegutses mainekas Suride rahvaarstidünastia (vt Kõivupuu 2004, http://www.folklore.ee/pubte/rahvaarstid/), siis mindi tervisehädadega nähtavasti eelkõige ravitseja(te) juurde või ravitseja(te) hauale. Tänapäeva inimesed, kes enda väitel ei ole seotud ühegi religiooni või usundiga, kelle maailmapilt on nende endi sõnul materialistlik, loodusteaduslik, võivad looduses kogeda meeldivaid tundeid, vaimse ja füüsilise jõu taastumist, vaimset kirgastumist - erilised või pühaks peetavad paigad looduses on (ka) füüsilise ja vaimse tervise läteteks (Verschuuren \& Wild et al. 2010: 2-3; Rønnow 2011). Lisaks suulisele ja varasemate põlvede poolt kirjapandud pärimusele vahendab ja kinnistab tänapäeval nii kõnelev, kirjutav kui ka elektrooniline meedia looduse sakraliseerimisega seotud individuaalseid või kogukondlikke religioosseid praktikaid ja kogemusi, mida viljeldakse ka pühapaikades (müntide annetamine pühapuude juurde või pühadele kividele). 
Rõhutamist väärib ka asjaolu, et kohapärimuslikku või usundilist teavet sisaldavaid folklooritekste ei saa ega tohi kasutada kui ajalooürikut ning folklooritekstides esinevaid toponüüme kui n-ö bibliomeetrilist mõõdikut. Väärate lõuna-eestikeelsete kohanimekirjutuste või sama paiga kohta kasutatavate paralleeltoponüümide põhjal on võimalik luua soovi korral pettekujutus rohkematest (püha)paikadest maastikul kui neid tegelikult on või oli (vt nt Vorsti, Arsti pro Horsti(palu), ka Lutsupalu; Tiinüs pro Tinnüs jpt). Arheoloog Andres Tvauri on looduslikest pühapaikadest kõneldes võtnud kasutusele ka siinkirjutajale sümpaatse termini "pärimusmälestised" - lähtudes tõsiasjast, et enamik teateid ühe või teise koha pühaks pidamise ja ohverdamiskommete kohta pärinevad rahvaluule kogumise kõrgperioodist 19. ja 20. sajandi vahetusel ning vahel on nende üleskirjutuste põhjal ütlemata raske kindlaks teha, millisest konkreetsest pühakohast ikkagi ühes või teises pärimustekstis kõneldakse (Tvauri 2007: 6-7). Hargla kihelkonna kohapärimuse põhjal võib väita, et koguja Anton Suurkase kirja pandud tekstid on maastikul reaalsete kohtade leidmiseks üsna ebausaldusväärsed: tekstid on tõenäoliselt kompileeritud, toponüümika on eksitav või koguni vale; kuid teisalt peegeldavad need tekstid kohapärimust kui kunstilist teksti, kuhu on summeeritud kollektiivsesse mällu talletunud väärtushinnagud ja arusaamad.

Nüüdisaegses globaliseeruvas maailmas muutub üha tähtsamaks maastike mitmekesisuse säilitamine, kohavaimu ja -tähenduste otsimine ning kohaliku ja omapärase rõhutamine, mis on otseselt või kaudselt seotud tänapäevase kohaturunduse ja turismindusega ning rahvusliku identiteedi (re)konstrueerimisega.

Looduslike pühapaikade, kuid ka teiste maastikul tähendust omavate paikade teaduslikul uurimisel tuleks aga senisest rohkem tähelepanu pöörata Eestisisestele regionaalsetele erisustele, mida omakorda on kujundanud looduslikud olud ja piirkonna üldine kultuuritaust. Kogukonda ümbritsev maastik ei ole staatiline, vaid dünaamiline ruum, milles tekivad või luuakse kogukonna elu peegeldavad uued tähendused. Ka looduslikud pühapaigad ei ole ses suhtes erandid - kuigi paljude looduslike pühapaikade tähtsus ja tähendus on ajalooline, ei ole nad ajas ja ruumis muutumatud. Tingimuste ja ümbruse muutumine võib kaasa tuua ka uute pühapaikade tekke ja/või vanade unustamise. Kuid sealjuures tasub alati meeles pidada, et maastikus leiduvad sakraalpaigad on ainult üks paljudest võimalikest viisidest või võimalustest, kus usundid või religioonid suhtestuvad looduse ja maastikega (Verschuuren \& Wild et al. 2010: 2-3).

\section{Kommentaarid}

1 Artikli valmimist toetas Eesti teadusagentuur IUT3-2 ja Euroopa Liit Euroopa Regionaalarengu Fondi (Kultuuriteooria Tippkeskus) kaudu. 
${ }^{2}$ Mõiste 'ökoloogia' (s.o teadus, mis uurib suhteid ja protsesse ökosüsteemides) võttis 1866. aastal kasutusele Ernst Haeckel. Maastiku-uuringutega tegeleb maastikuökoloogia. Alates 1960.-70. aastaist sai ökoloogia nn rohelise ideoloogia maailmavaateliseks aluseks, ning sõna ökoloogiline omandas lisatähenduse kui keskkonnasõbralik, säästlik ja teiste liikidega arvestav.

${ }^{3}$ Looduslike pühapaikade ja arheoloogiamälestiste inventeerimine toimus siinkirjutaja juhtimisel koostöös Tallinna Ülikooli Eesti Humanitaarinstituudi maastiku ja kultuuri keskuse ning Tartu Ülikooli ajaloo ja arheoloogia instituudiga ajaloolise Võrumaa Hargla kihelkonnas projekti "Arheoloogia, võim, ühiskond: Koostöö arheoloogiapärandi kaitseks" raames 2012. aasta augustis ja septembris. Looduslikke pühapaiku ja arheoloogiamälestisi inventeerisid Marju Kõivupuu, Kristiina Tiideberg, Anneliis Peterson ja Kaarel Kõivupuu.

4 Arheoloogiamälestiste puhul on ohuks matusepaikade (kalmete) ja asulakohtade rüüstamine, arheoloogilise kultuurikihi hävitamine varanduste hankimise eesmärgil.

5 Loe lähemalt: http://www.monistemuuseum.ee/; http://www.monistemuuseum.ee/ ajalugu (25. november 2013).

6 1846. aastast pärineb esimene märkus Ädiste ja Lutsupalu (Horsti talu maal) kooli kohta. (Need arvatakse olevat kaks von Koskülli asutatud kooli, nagu ta seda oli lubanud.) Ädistes on õpetajaks keegi, kes ei oska kirjutada, saab lahti selle eest ja asemele Peeter Kuus, Lutsupalus on õpetajaks jälle suur joodik, kes sellepärast lahti lastakse (http://www.folklore.ee/pubte/ajaloolist/hargla/hargla.html).

7 Soot, soodi - jõesängist eraldunud looge, milles on harilikult järv või soo, vanajõgi.

8 2000. aasta 6. oktoobril sai loendatud Sarupalu ristipuud: ühe ristiga mände 255, kahe ristiga 80, kolme ristiga mände 38, nelja ristiga 17, viie ristiga 6 ja kuue ristiga mände 5. Kokku 401 puud ja 657 ristimärki. 2012. aasta loendusandmed on samas suurusjärgus.

9 Vt nt Nele Reimanni koostatud Võromaa kodolugu (Võro Instituut 2004), 1980. aastate lõpust järjepidevalt ilmuvad Võro-Seto tähtraamatud jms.

\section{Käsikirjad}

Mõniste ümbruse ajalugu. Koostaja P. Kenk. Originaalkäsikiri asub Mõniste muuseumis, koopia M. Kõivupuu valduses.

M. Kõivupuu 1990. aastate välitööde päevikud ja materjalid M. Kõivupuu valduses.

\section{Arhiiviallikad}

EKLA - Eesti Kirjandusmuuseumi Eesti kultuurilooline arhiiv

ERM EA - Eesti rahva Muuseumi etnograafiline arhiiv

RKM - Eesti Kirjandusmuuseumi Riikliku kirjandusmuuseumi rahvaluulekogu (alates 1945. aastast) 


\section{Elektroonilised andmebaasid}

Eesti Keele Instituudi kohanimede kartoteek http://heli.eki.ee/kohanimed/index. php?khk=har\&d_info=o-\%C3\%BC\&om=es2\&st=86317\&a=121 (27. november 2013).

EELIS ehk keskkonnainfo andmebaas http://loodus.keskkonnainfo.ee/WebEelis/infoleht. aspx?type=artikkel\&id=-294849174 (27. november 2012).

Eesti muinsuskaitse all olevate pühapaikade loend http://www.maavald.ee/failid/Lisa2_ muinsuskaitse.pdf (27. november 2012).

Lõuna-Eesti pärimuse portaal LEPP Hargla, Karula ja Urvaste khk: http://www.folklore. ee/lepp/ (27. november 2013); http://www.folklore.ee/lepp/hargla/ (27. november 2013); http://www.folklore.ee/lepp/karula/ (27. november 2013); http://www.folklore.ee/lepp/ urvaste/ (27. november 2013).

Keskkonnaameti infovoldik: Koiva-Mustjõe maastikukaitseala http://www. keskkonnaamet.ee/public/Koiva-Mustjoe_A4_est.pdf (27. november 2013).

Kivirähk, Alfred 2007. Hargla kihelkonnast 1927. a. suvel kogutud ajalooline traditsioon. Tartu: Eesti Kirjandusmuuseum (http://www.folklore.ee/pubte/ajaloolist/hargla/hargla. html - 27. november 2013).

Ristipuude kaart http://www.roheline.ee/ristipuud/ (27. november 2013).

\section{Kirjandus}

Alekand, Katrin \& Metsvahi, Merili 2013. Kultuuriteooria tippkeskuse VI sügiskonverents: Kehapärimus. Intervjuu Katherine Youngiga. Sirp 40, 25. oktoober, lk 5 (http://www. sirp.ee/index.php?option=com_content\&view=article\&id=19777:2013-10-24-12-12-05\&ca tid=9: sotsiaalia\&Itemid=13\&issue $=3462-27$. november 2013).

Claval, Paul 2004. The Languages of Rural landscapes. Palang, Hannes \& Sooväli, Helen \& Antrop, Marc \& Setten, Gunhild (toim). European Rural Landscapes: Persistence and Change in a Globalising Environment. Dordrecht: Kluwer Academic Publishers, lk 11-40 (doi: 10.1007/978-0-306-48512-1_2).

Cosgrove, Denis 2003. Landscape: ecology and semiosis. Palang, Hannes \& Fry, Gary (toim). Landscape Interfaces. Cultural Heritage in Changing Landscapes. Dordrecht: Kluwer Academic Publishers, lk 15-20 (doi: 10.1007/978-94-017-0189-1_2).

Fox, James (toim) 1997. The Poetic Power of Place: Comparative Perspectives on Austronesian Ideas of Locality. Research School of Pacific Studies. Canberra: The Australian National University (https://pure.au.dk/portal/files/36241420/Poetics_of_ Place_book_1998_.pdf - 27. november 2013).

Hiiemäe, Mall 2007. Pühapaigad kui mentaalse maastiku objektid: mõiste ja väljund. Kaasik, Ahto \& Valk, Heiki (koost). Looduslikud pühapaigad. Väärtused ja kaitse. Õpetatud Eesti Seltsi Toimetised 36. Tallinn: Maavalla Koda, lk 215-238 (http://maavald. ee/hiis/raamat2007/hiiekogumik.pdf - 27. november 2013).

KrEm 2003 = Fairclough, Graham \& Darlington, John \& Clark, Jo \& Kraut, Ants \& Solnask, Helle (toim). Kultuurirajad Euroopa maastikul: kultuurirajad Euroopa muinasmaastikel 2000-2003. Germany: PCL. 
Kõivupuu, Marju 2004. Rahvaarstid. Noor ja vana Suri Võrumaalt (http://www.folklore. ee/pubte/rahvaarstid/ - 27. november 2013).

Kõivupuu, Marju 2009. Hinged puhakavad puudes. Tallinn: Huma.

Lõugas, Vello \& Selirand, Jüri 1989. Arheoloogiga Eestimaa teedel. Tallinn: Valgus.

Pink, Sarah 2000. Informants' who come 'home'. Amit, Vered (toim). Constructing the Field. Ethnographic Fieldwork in the Contemporary World. London \& New York: Routledge, lk 96-119.

Relph, Edward 1976. Place and Placelessness. London: Pion.

Remmel, Mari-Ann 2007. Hiiepärimuse sõnum tänases Eestis: lähteandmeid ja tõlgendusvõimalusi. Kaasik, Ahto \& Valk, Heiki (koost). Looduslikud pühapaigad. Väärtused ja kaitse. Õpetatud Eesti Seltsi Toimetised 36. Tallinn: Maavalla Koda, lk 239-262 (http://maavald.ee/hiis/raamat2007/hiiekogumik.pdf - 27. november 2013).

Rønnow, Tarjei 2011. Saving Nature. Religion as Environmentalism, Environmentalism as Religion. Studies in religion and the Environment 4. Berlin: LIT Verlag.

Ruotsala, H. 2001. Fieldwork at home: Possibilities and limitations of native research. Runnel, Pille (toim). Rethinking Ethnology and Folkloristics. Vanavaravedaja 6. Tartu, lk 111-131.

Siikala, Anna-Leena 1998. Kuuluvuspaigad: ajaloo taasloomine. Mäetagused 26, lk 53-68 (http://www.folklore.ee/tagused/nr26/siikala.pdf - 27. november 2013).

Tvauri, Andres 2007. Millest kõnelevad ohvri- ja lohukivid. Eesti Loodus 10, lk 6-13.

Verschuuren, Bas \& Wild, Robert \& Mcneely, Jeffrey A. \& Oveideo, Gonzalo (toim) 2010. Sacred Natural Sites. Conserving Nature \& Culture. London: Earthscan.

Weiner, James F. 1991. The Empty Place: Poetry, Space, and Being Among the Foi of Papua New Guinea. Bloomington: Indiana University Press.

Wright, J. K. 1947. Terrae Incognitae: The place of imagination. Geography Annals of the Association of American Geographers 37, lk 1-15.

\section{Summary}

\section{Lore in Landscape, Landscape in Lore: On the Example of Hargla Parish}

\section{Marju Kõivupuu}

Keywords: Hargla parish, chapel sites, place lore, natural sacred sites, funeral traditions, folk belief

The article provides an overview of the dynamics of local lore in Hargla parish, its importance and meaning, as well as the influencing factors in the cultural space of a parish nowadays. The article is based on the fieldwork carried out in Hargla parish during the summer of 2012, with an aim to inventory the natural sacred sites, archaeological monuments and collection of oral heritage concerning those sites. 